\title{
Rancang Bangun Dan Peran Benteng Sumenep
}

\section{Novida Abbas}

Keywords: fort, defense, British, colonial, trade, madura

\section{How to Cite:}

Abbas, N. (2006). Rancang Bangun Dan Peran Benteng Sumenep. Berkala Arkeologi, 26(1), 1-11. https://doi.org/10.30883/jba.v26i1.919

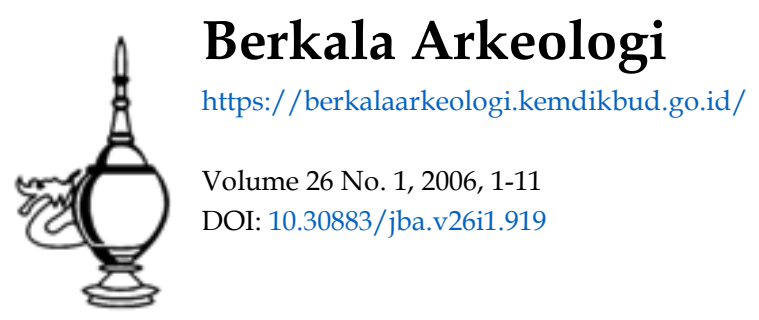

\section{(c) (i) (3)}

This work is licensed under a Creative Commons Attribution-NonCommercial-ShareAlike 4.0 International License. 


\section{RANCANG BANGUN DAN PERAN BENTENG SUMENEP \\ Novida Abbas}

\section{PENDAHULUAN}

\section{A. Latar Belakang}

Benteng-benteng Belanda yang berasal dari abad XVII-XIX ditemukan tersebar di berbagai wilayah di Indonesia. Selain di Maluku, jumlah terbesar keberadaan benteng Belanda terdapat di Jawa. Di Pulau Madura, yang secara administratif masuk dalam wilayah Jawa Timur, terdapat pula 2 benteng Belanda, salah satunya di Sumenep. Sumenep beserta bagian-bagian lain dari Pulau Madura awalnya berada di bawah hegemoni Mataram sampai sekitar abad XVIII. Pada tahun 1705 Sumenep dan Pamekasan yang terletak di bagian timur pulau diberikan kepada VOC (Heeres, 1935: 244). Sejak itu Sumenep harus mengirim berbagai produk daerah untuk kepentingan VOC. Selain itu, untuk kepentingan militer VOC, penguasa Sumenep mendirikan dan memelihara sebuah benteng kecil di dekat ibukota (de Jonge, 1989: 15). Semula benteng tersebut mempunyai fungsi sipil maupun militer, dengan ditunjuknya seorang pedagang atau perwira rendah untuk mengepalai benteng tersebut. Hingga akhimya pada tahun 1780-an ditunjuk seorang komandan militer untuk benteng itu.

Seperti disebutkan dalam catatan sejarah, pada tahun 1705 Sumenep dan Pamekasan jatuh ke tangan VOC (Heeres, 1935: 244). Disebutkan pula bahwa benteng Belanda di Sumenep didirikan pada tahun 1785 dan dihuni oleh 25 sampai 30 serdadu Eropa, dengan persenjataan berupa 4 pucuk meriam dan dikomandani oleh seorang letnan (Hageman, 1858: 329). Ketika "Hindia-Belanda" diduduki Inggris pada tahun 1811, Sumenep ditaklukkan setelah melalui suatu perlawanan sengit (de Jonge, 1989: 19). Pada masa itu disebutkan bahwa kondisi fisik benteng Sumenep dalam keadaan buruk dan hanya digunakan sebagai gudang penyimpanan logistik (Thom, 1993: 312). Selanjutnya menurut keterangan nara sumber, pada 
masa pendudukan Jepang benteng ini digunakan sebagai rumah sakit, setelah kemerdekaan sebagai tempat penyimpanan garam, dan saat ini dimanfaatkan oleh Dinas Peternakan sebagai tempat transit ternak.

\section{B. Permasalahan}

Dari beberapa sumber yang diperoleh mengenai eksistensi benteng Belanda di Sumenep, tampak bahwa terdapat berbagai peristiwa yang terjadi selama masa guna benteng tersebut. Selain itu terdapat pula beberapa hal yang saling bertentangan yang masih memerlukan penjelasan lebih lanjut. Berbagai sumber menyebutkan bahwa pada awalnya benteng Sumenep memiliki fungsi militer maupun sipil, yang tampak dan penyebutan benteng tersebut sebagai tempat tinggal wakil perdagangan Belanda, meskipun pada akhimya benteng tersebut hanya berfungsi militer saja, yaitu dengan ditambahnya pasukan yang mendiami benteng dan ditunjuknya seorang letnan sebagai komandan benteng. Juga adanya perlawanan terhadap Inggris, yang kemungkinan melibatkan benteng sebagai salah satu sarana pertahanan.

Di sisi lain, menyangkut masa pendirian benteng itu sendiri, sebuah sumber menyiratkan bahwa benteng Sumenep telah eksis pada sekitar akhir abad XVII, sementara sumber lain menyebutkan bahwa pendirian benteng dilakukan pada akhir abad XVIII. Pada umumnya benteng-benteng Belanda dari sebelum abad XIX pada awal pendiriannya dibangun dengan menggunakan bahan-bahan semipermanen, misalnya kayu dan bambu. Di masa-masa selanjutnya banyak benteng yang dibangun ulang dengan menggunakan bahan-bahan permanen seperti batu atau bata. Pembangunan ulang semacam itu biasanya juga merubah denah benteng yang bersangkutan. Hal semacam ini antara lain terjadi pada Benteng Vredeburg, Yogyakarta (Poensen, 1901: 223-361) dan benteng Panarukan (Stockdale, 1995: 369-371).

Berdasarkan hal-hal tersebut di atas, permasalahan yang diajukan dalam penelitian ini adalah bagaimana seni bangun dan denah benteng Sumenep secara lengkap serta aktivitas apa saja yang pernah terjadi di dalam dan di sekitar lingkungan benteng tersebut, terutama pada masa gunanya, dengan tidak 
mengabaikan kemungkinan untuk melacak sisa aktivitas pada masa pra maupun pasca penggunaan benteng.

\section{Tujuan dan Sasaran Penelitian}

Penelitian benteng Sumenep secara keseluruhan telah dilaksanakan dalam 4 tahap, yaitu sejak tahun 2002 sampai 2005. Tujuan akhir penelitian adalah rekonstruksi arsitektur dan peran benteng Sumenep sejak benteng tersebut didirikan hingga ditinggalkan. Sasaran akhir penelitian adalah rancang bangun dan denah benteng Sumenep serta pemahaman mengenai berbagai jenis aktivitas yang pemah berlangsung di dalam dan di lingkungan sekitar benteng, baik sebelum, selama, dan sesudah masa guna benteng tersebut.

\section{Kerangka Pikir}

Penelitian ini ditujukan untuk memperoleh gambaran mengenai peran maupun rancang bangun benteng Sumenep pada masa gunanya. Kedua aspek itu merefleksikan sistem pertahanan Belanda pada abad XVII-XVIII. Kebijakan Belanda pada masa-masa itu menunjukkan berbagai perubahan, dari ekspansi ekonomi ke ekspansi politik. Secara bertahap, tujuan mereka(Belanda) berubah dari ekonomi ke perluasan wilayah (Campbell, 1919, 1).

Benteng dilihat sebagai data fisik, bukanlah semata-mata sebuah fenomena kepentingan militer semata. Benteng didirikan di suatu tempat tentunya berdasarkan pertimbangan-pertimbangan strategi atau ekonomi tertentu. Beberapa benteng juga dapat dikategorikan ke dalam permukiman permanen ataupun semi-permanen (Knudson, 1985: 410), sebab biasanya benteng dihuni oleh setidak-tidaknya sekelompok pasukan untuk suatu jangka waktu tertentu, meskipun jumlah populasi di sebuah benteng adalah tidak pasti, karena dapat berubah sewaktu-waktu, tergantung pada berbagai situasi yang dihadapi benteng itu di masa gunanya.

Besar kecilnya luasan suatu benteng, keragaman bangunan yang ada di bagian dalamnya, serta keragaman data artefak yang tertinggal di dalam maupun di sekitar benteng, dapat merefleksikan seberapa besar peran suatu benteng pada masa gunanya. Meskipun demikian, penting tidaknya peran suatu benteng juga bervariasi dari satu masa ke masa lainnya dan bukan merupakan kualitas yang tidak mungkin 
berubah, bergantung pada berbagai faktor yang dihadapi (Murfett et al., 1999: 1$3)$.

\section{Metode Penelitian}

Tujuan penelitian seperti tersebut di atas dicapai melalui penerapan metode penelitian deskriptif dengan penalaran induktif. Pengumpulan data di lapangan dilakukan melalui survei dan ekskavasi pada bagian dalam maupun luar benteng, dengan membuka kotak-kotak gali berukuran $2 \mathrm{~m} \times 2 \mathrm{~m}$ dan dalam penggalian digunakan teknik spit berinterval $20 \mathrm{~cm}$.

Data utama dalam penelitian ini adalah data arkeologis berupa artefak dan struktur bangunan. Selain itu digunakan pula data sejarah sebagai penunjang. Denah, rancang bangun, maupun ukuran bangunan diungkapkan melalui unit analisis berupa data bangunan, sementara ragam aktivitas diungkapkan melalui unit analisis berupa

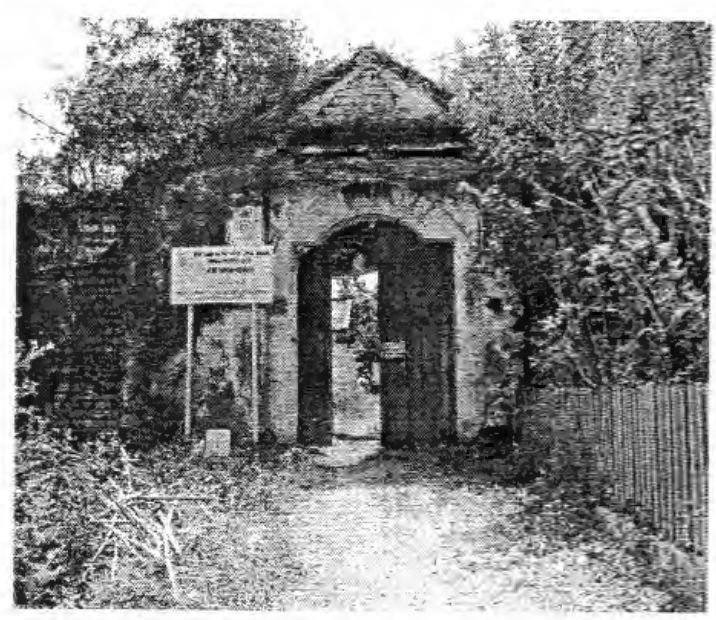

Foto 1. Pintu masuk Benteng Sumenep artefak, baik secara kuantitas maupun kualitas.

\section{HASIL PENELITIAN DI BENTENG SUMENEP}

Situs benteng Sumenep terletak sekitar $7 \mathrm{~km}$ di sebelah tenggara kota Sumenep, yaitu ke arah pelabuhan Kalianget. Lokasi ini secara administratif termasuk dalam wilayah desa Kalimo'ok, Kecamatan Kalianget, Kabupaten Sumenep, Jawa Timur. Benteng Sumenep terletak sekitar $200 \mathrm{~m}$ di sebelah utara Sungai Marengan atau sekitar $3 \mathrm{~km}$ dari pantai. Areal benteng ini datar dan penuh dengan vegetasi yang cukup lebat. Di bagian dalam benteng, yaitu di sudut timur laut terdapat sebuah bangunan yang diduga dulunya merupakan tempat penyimpanan amunisi, mengingat bangunan tersebut hanya memiliki sebuah pintu masuk dan tidak berjendela. Saat ini bekas benteng tersebut digunakan oleh Proyek Pengembangan Ternak Kecil, Dinas Peternakan Kab. Sumenep. Dengan fungsi barunya tersebut, sejumlah bangunan baru telah didirikan 


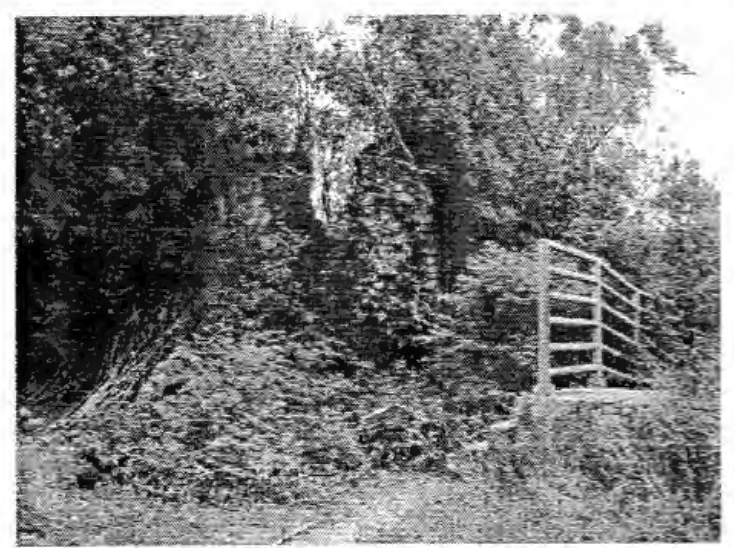

Foto 2. Kondisi bastion tenggara saat ini

di bagian dalam maupun di sekitar benteng. Di sebelah utara dan timur benteng terdapat bangunan-bangunan kandang sapi dan kantor proyek serta jalan semen, sementara di sebelah barat ditumbuhi semak belukar yang cukup lebat, dan di sisi selatan terdapat jalan masuk menuju benteng. Di sebelah barat daya benteng terdapat kompleks makam Belanda yang berasal dari tahun 1932, seperti yang tertera pada gapura kompleks makam. Di bagian dalam benteng agak ke tengah terdapat sebuah bangunan baru yang digunakan sebagai tempat tinggal penjaga proyek. Benteng ini sendiri memiliki 2 pintu masuk, yaitu di sisi selatan dan utara. Pintu masuk utama adalah yang terdapat di sisi selatan, sehingga benteng ini memiliki arah hadap ke selatan. Secara keseluruhan dapat dikatakan bahwa . dinding keliling benteng ini masih relatifutuh, meskipun di beberapa tempat terdapat bagian-bagian yang runtuh, retak, maupun rusak.

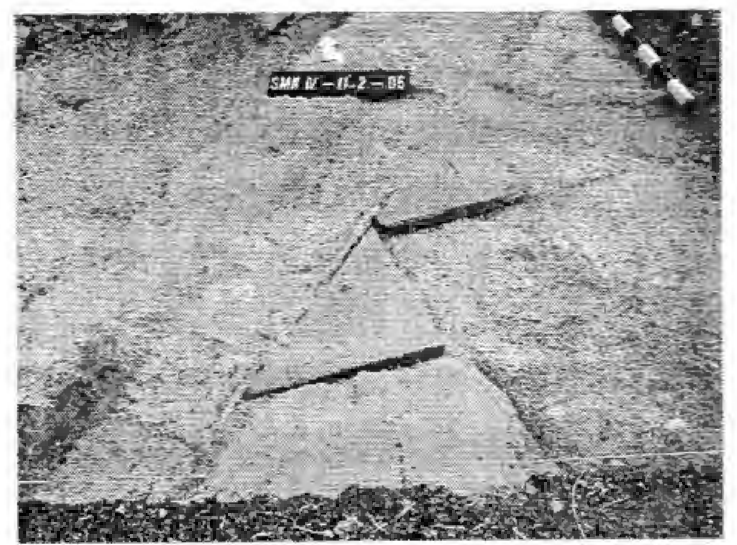

Foto 3. Lantai terakota hasil ekskavasi

\section{Struktur Bangunan}

Struktur bangunan ditemukan pada sebagian besar kotak gali yang berada di dalam benteng. Struktur bangunan yang ditemukan selama penelitian berupa struktur fondasi dan struktur dinding berbahan batu putih, sisa lantai dari ubin terakota maupun plesteran semen, saluran air/parit, dan sumur atau lubang pembuangan sampah berbahan batu putih.

Temuan struktur fondasi di bagian tengah agak ke belakang benteng menunjukkan bekas sebuah bangunan yang berukuran $9 \mathrm{~m} \times 9 \mathrm{~m}$, di bagian dalam berlantai terakota yang disusun secara diagonal, dan di bagian luar yang kemungkinan merupakan semacam selasar, berlantai plesteran semen. Ubin terakota yang merah 
digunakan pada bangunan ini berukuran $30 \mathrm{~cm}$ x $30 \mathrm{~cm}$. Selain itu, ditemukan struktur parit di sisi luar bangunan. Parit tersebut memiliki lebar $20 \mathrm{~cm}$. Temuantemuan tersebut diatas

kemungkinan merupakan bekas sebuah bangunan yang memiliki pintu masuk yang terletak satu garis lurus dengan kedua pintu masuk benteng, atau memiliki lorong di bagian tengah yang membagi bangunan tersebut menjadi dua bagian. Dua bagian di kiri dan kanan lorong tersebut disekat menjadi ruang-ruang. Hal ini ditunjukkan dari temuan struktur lantai di bagian tengah yang menunjukkan perbedaan dengan struktur lantai di bagian lain. Selain itu tampak pula bekas dinding penyekat yang memisahkan ruang di kiri dan kanan lorong menjadi beberapa ruang lain. Di bagian luar bangunan terdapat parit pembuangan. Sementara itu di bagian barat benteng agak ke utara terdapat sisa bangunan lain yang belum jelas denahnya.

Selain itu di dekat tembok benteng sisi selatan ditemukan parit/saluran air selebar $24 \mathrm{~cm}$ yang menyalurkan air dari dalam lingkungan benteng menuju ke luar. Hal ini dibuktikan pula dengan adanya 4 lubang pembuangan, masing-masing dua di dinding selatan dan dinding utara. Parit tersebut ditemukan dengan tatanan batu putih di atasnya yang merupakan batu penutup parit.

Selanjutnya di sudut barat laut benteng ditemukan pula struktur melingkaryang belum diketahui dengan jelas apakah merupakan sumur atau tempat pembuangan sampah, mengingat di dalam struktur tersebut ditemukan sejumlah besar fragmen tembikar, fragmen kaca/gelas, fragmen keramik, fragmen logam, maupun fragmen tulang binatang.

\section{Temuan Artefaktual}

Temuan artefaktual dari ekskavasi selama 4 tahap di lokasi benteng terdiri atas fragmen tembikar, fragmen keramik, fragmen kaca/gelas, terakota, dan fragmen logam. Selain itu ditemukan pula fragmen tulang dan gigi.

Temuan tembikar berasal dari 4 jenis wadah, yaitu kuali, jambangan, mangkuk, dan tempayan. Wadah-wadah tersebut memiliki variasi warna permukaan dari 
merah terang, coklat kemerahan, dan coklat kehitaman. Warna permukaan merah terang umumnya berasosiasi dengan irisan berwarna gelap yang menunjukkan proses pembakaran yang kurang sempuma. Hal ini juga terjadi pada permukaan berwarna coklat kehitaman dengan irisan berwarna gelap. Warna permukaan coklat kemerahan berasosiasi dengan irisan warna senada, yang menunjukkan adanya pembakaran yang cukup sempurna. Dari pengamatan terhadap permukaan temuan diketahui bahwa wadah-wadah tersebut dibuat dengan menggunakan roda pemutar, yang tampak dari adanya bekas-bekas striasi. Penyelesaian permukaan sebagian besar wadah dilakukan tanpa pengupaman, hanya sedikit yang menunjukkan adanya bekas pengupaman. Adonan yang digunakan berupa tanah liat dengan temper pasir dan ada yang bertemper pasir dan sekam. Sejumlah kecil fragmen menunjukkan penggunaan hiasan dengan teknik gores bermotif geometris.

Analisis terhadap fragmen keramik menunjukkan adanya 4 jenis wadah, yaitu piring, mangkuk, cangkir, dan botol. Sebagian besar temuan berupa keramik Eropa (Belanda) dari abad XIX-XX, dan sisanya merupakan keramik Cina dari dinasti Qing abad XVIII-XIX maupun keramik Cina modern dari abad XX. Fragmen keramik tersebut sebagian besar berbahan porselin (porcelain) berwarna putih, dan sebagian kecil berbahan batuan (stoneware) berwarna abu-abu.

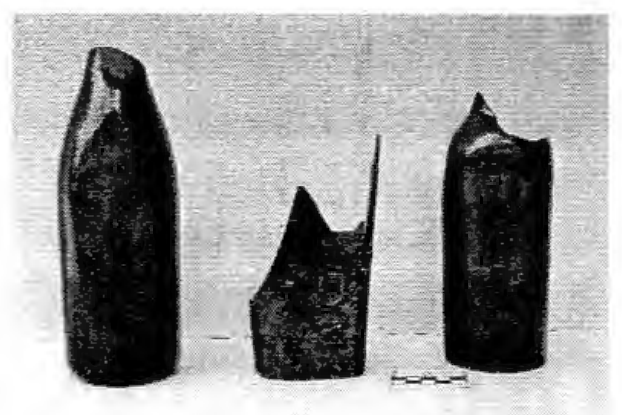

Foto 4 . Temuan fragmen botol

Temuan artefaktual yang dari segi kuantitas terbanyak jumlahnya adalah temuan fragmen $\mathrm{kaca} / \mathrm{gelas}$. Fragmen kaca/gelas dari ekskavasi ini berasal dari enam jenis wadah, yaitu botol, toples, gelas, cepuk, lampu minyak, dan ampul. Warna temuan-temuan tersebut adalah putih, hijau, coklat, coklat kekuningan, dan biru. Temuan terbanyak berupa botol dengan berbagai variasi, baik yang berleher pendek maupun panjang, berdasar bulat, lonjong dan persegi. Pada beberapa botol terdapat tulisan di bagian badannya, di antaranya bertulisan: ...IUWA ...; LEVER...SCHO...HAARLEM; MIL...; RYKS EIGENDOM; NHEYM....ET.

Selain itu banyak dijumpai bagian dasar botol yang mengandung tulisan maupun 


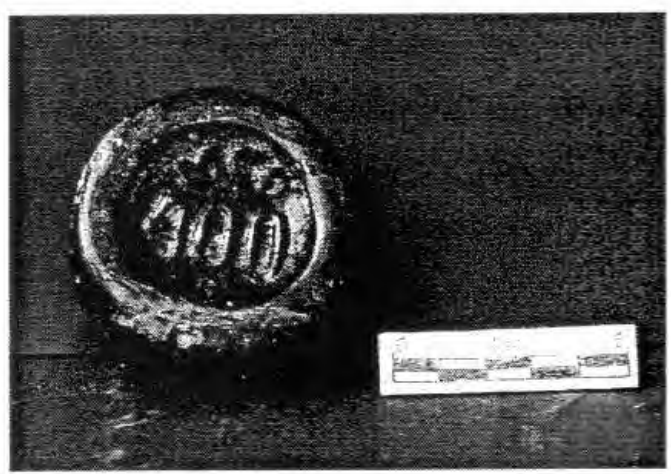

Foto 5. Temuan dasar botol bertulisan MGD 400 angka, yaitu sebagai berikut: PATENT $\boldsymbol{V}$ TORLEY, MGD $750 \mathrm{~B}, 30, M G D 500 \mathrm{~B}$, $M G D 400$ M, MGD 200, dan 1500. Angka pada dasar botol tersebut mengacu pada volume botol, yang berkisar antara $30 \mathrm{ml}$ sampai $1500 \mathrm{ml}$. Fragmen gelas ditemukan dalam 2 jenis, yaitu gelas berkaki dan gelas tanpa kaki. Selanjutnya terdapat pula temuan berupa ampul yang dulunya berisi cairan obat ataupun untuk cairan suntikan, terlihat dari lubang

ampul yang kecil tempat memasukkan jarum suntik.

Benda-benda logam yang ditemukan dalam ekskavasi sebagian besar berupa unsur bangunan, seperti engsel, paku, pegangan pintu, teralis, dan kawat. Temuan tersebut telah teroksidasi, sehingga permukaannya kasar dan penuh karat berwarna coklat tua dengan bercak-bercak jingga. Selain itu ditemukan pula 3 mata uang. Salah satunya bertulisan Y.O.C. dan berangka tahun 1760, sebuah lainnya bertulisan Nederlandsch Indie dengan angka tahun 1840, sementara satu buah sisanya tidak dapat diidentifikasi karena sangat aus.

\section{BANGUNAN-BANGUNAN DI DALAM BENTENG DAN GAMBARAN AKTIVITASNYA}

Di bagian dalam benteng, tepatnya di bagian belakang benteng sekitar $4 \mathrm{~m}$ dari tembok belakang (tembok utara) benteng, terdapat sebuah bangunan berdenah bujur sangkar berukuran $9 \mathrm{~m} \times 9 \mathrm{~m}$. Bangunan yang letaknya sejajar dengan tembok utara benteng tersebut dibuat dari batu putih dan berlantai ubin terakota yang disusun secara diagonal. Di bagian luar bangunan terdapat semacam selasar yang berlantai plesteran semen. Menempel pada bagian timur bangunan terdapat saluran air/parit selebar $20 \mathrm{~cm}$.

Menurut keterangan nara sumber, di bagian belakang benteng dulunya terdapat 2 buah barak prajurit yang dipisahkan oleh sebuah lorong. Pembuktian keterangan nara sumber melalui ekskavasi telah menghasilkan data mengenai keberadaan 
sebuah bangunan seperti tersebut di atas. Mengenai lorong yang membagi bangunan tersebut ke dalam 2 bagian telah terbukti pada penelitian tahap ini. Hasil ekskavasi pada bagian yang merupakan as atau poros bangunan menghasilkan data mengenai cara pemasangan ubin terakota yang berbeda dengan yang terdapat di bagian lain bangunan. Di bagian ini ditemukan lantai terakota yang disusun sejajar, tidak diagonal. Data ini dapat merupakan bukti adanya lorong, yang berlantai terakota sejajar, sementara bagian bangunan lain berlantai terakota diagonal, ataupun adanya pintu masuk ke dalam bangunan itu sendiri. Sementara di kiri kanan lorong tersebut masing-masing terdapat tiga ruang yang dipisahkan oleh sekat berupa dinding batu putih.

Temuan artefaktual terutama didapatkan pada kotak-kotak gali di sudut barat laut benteng yang tampaknya merupakan tempat pembuangan sampah pada masa guna benteng tersebut. Temuan tersebut sebagian besar berupa alat keperluan sehari-hari, baik yang terbuat dari gelas/kaca, tembikar, maupun keramik. Temuan - logam umumnya berupa bagian dari bangunan, seperti engsel dan paku, yang kemungkinan merupakan bagian dari bangunan di dalam benteng itu sendiri. Sesuai dengan informasi yang diperoleh dari penduduk setempat, yaitu bahwa bangunan di bagian dalam benteng pernah dirobohkan dan puing-puingnya digunakan untuk mengurug bagian dalam benteng.

\section{REKONSTRUKSI ARSITEKTUR}

- Benteng Sumenep memiliki denah bujur sangkar dan berukuran $60 \mathrm{~m}$ x $60 \mathrm{~m}$ dengan arah hadap ke selatan dan memiliki 2 pintu masuk, yaitu 1 di selatan dan 1 di utara.

- Benteng memiliki bastion pada keempat sudutnya, dan masing-masing bastion saling terhubung dengan selasar selebar $4 \mathrm{~m}$. Pada tiap bastion terdapat 6 tempat meletakkan meriam.

- Sekurang-kurangnya terdapat 1 tangga naik di sudut barat daya benteng.

- Di bagian dalam benteng paling tidak terdapat 5 bangunan, dan 1 di antaranya masih berdiri di sudut timur laut benteng, yaitu yang berupa gudang mesiu.

$\mathrm{n}$ Bangunan di dalam benteng dibuat dari batu putih dengan lantai terakota. Ubin terakota di bangunan-bangunan tersebut memiliki dua variasi ukuran, yaitu $40 \mathrm{x}$ 
$40 \mathrm{~cm}$ dan $30 \times 30 \mathrm{~cm}$.

- Tiap bangunan memiliki saluran air yang dialirkan ke luar benteng melalui 4 lubang pembuangan, yaitu 2 di dinding selatan dan 2 di dinding utara benteng.

\section{PERAN BENTENG SUMENEP}

- Aktivitas selama masa guna benteng tampaknya merupakan aktivitas seharihari, seperti yang tercermin dari temuan artefaktual hasil ekskavasi. Sementara aktivitas militer tidak terbukti dari temuan artefaktual tersebut.

- Mengingat faktor keletakan benteng dan juga ditunjang oleh temuan ekskavasi, dapat disimpulkan bahwa di masa gunanya benteng Sumenep bukan merupakan benteng yang mempunyai peran besar dalam sistem pertahanan Belanda. Mengingat adanya toponim Pabian di kelokan sungai Marengan sekitar $1 \mathrm{~km}$ di sebelah barat benteng, kemungkinan peran benteng ini di masa gunanya lebih pada pengawasan jalur lalu lintas sungai untuk ke luar masuk pelabuhan lama tersebut $($ Pabian $=$ pelabuhan $)$.

- Pada masa pasca penggunaan benteng, benteng Sumenep ini digunakan sebagai rumah sakit, yaitu pada masa pendudukan Jepang. Selanjutnya pada masa kemerdekaan benteng ini dimanfaatkan sebagai gudang tempat penyimpanan garam, dan selanjutnya digunakan sebagai tempat karantina ternak sapi hingga saat ini.

\section{IV. "PERAN" BENTENG SUMENEP MASA KINI}

Benteng Sumenep, yang di masa lalu pernah berperan kecil ataupun besar dalam kehidupan politik maupun ekonomi Sumenep, saat ini hanya dibiarkan teronggok tidak terurus. Secara fisik, bangunan benteng ini sebenarnya masih berdiri dengan cukup utuh, meskipun beberapa bagian telah mengalami kerusakan. Menengok bagian lain di wilayah Kabupaten Sumenep, dapat dilihat bahwa potensi tinggalan budaya yang terdapat di wilayah ini cukup besar. Selama ini yang dikenal dari Sumenep terutama adalah bekas kraton Sumenep, masjid agung Sumenep, dan kompleks makam raja-raja di Asta Tinggi. Padahal sebenamya di luar itu masih banyak potensi tinggalan budaya yang belum digali dan dimanfaatkan dari Sumenep, seperti misalnya bangunan-bangunan bergaya Indis di sepanjang Sungai Marengan dan bangunan pabrik maupun perumahian milik PN Garam di Kalianget yang juga 
menunjukkan kekhasan gaya Indis. Sebagai sebuah tinggalan dari masa kolonial yang masih berdiri, benteng Sumenep seyogyanya dapat dilestarikan untuk dapat dimanfaatkan bagi kepentingan daerah. Dengan melestarikan objek im, dapat dikembangkan suatu "wilayah" baru dalam potensi yang dimiliki oleh Kabupaten Sumenep. Bersama dengan tinggalan lain yang juga menunjukkan pengaruh Indis, benteng Sumenep tentunya dapat dimanfaatkan lebih maksimal dari pada sekedar hanya digunakan sebagai tempat transit ternak saat ini.

\section{DAFTAR PUSTAKA}

Campbell, Donald Maclaine. 1915. Java: Past \& Present. Vol. I \& II. London. William Heinemann.

de Jonge, Huub. 1989. Pembentukan Negara dengan Kontrak: Kabupaten Sumenep, Madura, VOC dan Hindia Belanda, 1680-1883, dalam Huub de Jonge (ed.), Agama, Kebudayaan, dan Ekonomi. Jakarta. Rajawali Pers. Hlm. 1-30.

Hageman, J. 1858. Bijdrage tot de Kennis van de Residentie Madoera (eerste gedeelte), dalam T.N.I. 20ste jaargang, 1ste deel, hlm. 321-352. Zalt Bommel. Joh. Noman en Zoon.

Heeres, J.E. 1935. Verzameling van Politieke en Verdere Verdragen door de Nederlanders in het Oosten Gesloten, dalam B.K.I. Vol. VIII, hlm. 223-361. 's-Gravenhage. Martinus Nijhoff.

Murfett, Malcolm H., John N. Miksic, Brian P. Farrel, \& Chiang Ming Shun. 1999. Between Two Oceans: A Military History of Singapore from First Settlement to Final British Withdrawal. Singapore. Ox ford University Press.

Thom, William. Reprinted in 1993. The Conquest of Java. Singapore. Periplus Editions (HK) Ltd. 